\title{
Antiparasitic Efficiency of Artemisia absinthium on Toxocara cati in Naturally Infected Cats
}

\section{Doğal Enfekte Kedilerde Toxocara cati̊ ye Artemisia absinthium’un Etkisi}

\author{
Kader Yıldız', Mehmet Başalan², Özkan Duru³, Sami Gökpınar \\ ${ }^{1}$ Kırıkkale Üniversitesi Veteriner Fakültesi, Parazitoloji Anabilim Dalı, Kırıkkale, Turkey \\ ${ }^{2}$ Kırıkkale Üniversitesi Veteriner Fakültesi, Hayvan Besleme ve Beslenme Hastalıkları Anabilim Dalı, Kırıkkale, Turkey \\ ${ }^{3}$ Kırıkkale Üniversitesi Veteriner Fakültesi, Biyokimya Anabilim Dalı, Kırıkkale, Turkey
}

\begin{abstract}
Objective: The first aim of the present study was to determine the efficiency of A. absinthium extract on cats naturally infected with Toxocara cati. The second aim was to determine the efficiency of the extract on the embryonic development of T. cati eggs in vitro.

Methods: Artemisia absinthium extract was orally administrated to cats at the doses of $300 \mathrm{mg} / \mathrm{kg}$ and $600 \mathrm{mg} / \mathrm{kg}$ body weight in Group 1 and 2, respectively. It was given only once a day and the treatment continued 7 consecutive days. The faeces of the cats were examined both macroscopically and microscopically by flotation procedure with saturated salt solution pre-, during and post- treatment period. The faecal analysis was maintained during 8 days after completing the extract administration. The alteration of faecal egg numbers was performed by using the McMaster technique.

Results: The faecal egg numbers per gram were decreased gradually in cats in the trial groups. In the treatment period, the activities of ALT, AST, ALP, urea and creatinine were located within the physiological ranges in cats. In in vitro trials with $A$. absinthium extract, the embryonic development of T. cati eggs was identical in all groups (treatment and control). A. absinthium extract did not inhibit larval development in eggs in in vitro trials.
\end{abstract}

Conclusion: This plant extract may be an alternative choice in the treatment of parasitic diseases in future. (Turkiye Parazitol Derg 2011; 35: 10-4)

Key Words: Antiparasitic efficiency, Artemisia absinthium, cat, Toxocara cati

Received: 21.12 .2010

Accepted: 15.02 .2011

\section{ÖZET}

Amaç: Bu çalışmada Toxocara catiile doğal enfekte kedilere Artemisia absinthum ekstresinin etkinliğini ile in vitro ortamda T.catiyumurtasındaki embriyonik gelişime etkisinin belirlenmesi amaçlanmıştır.

Yöntemler: Artemisia absinthum ekstresi kedilere 300 mg/kg (Grup 1) ve 600 mg/kg (Grup 2) dozda ağızdan verilmiştir. Ekstre günde bir kez olacak biçimde 7 gün süreyle uygulanmıştır. Kedilerin dışkıları tedavi öncesinde, tedavi esnasında ve tedavi sonrasında makroskobik ve doymuş tuzlu su flotasyon yöntemi ile mikroskobik olarak incelenmiştir. Ekstre verilmesi bittikten sonraki 8 gün süreyle dışkı incelenmiştir. Dışkı yumurta sayısındaki değişim McMaster tekniği kullanılarak belirlenmiştir.

Bulgular: Deneme gruplarındaki kedilerde gram dışkıdaki yumurta sayısının dereceli olarak azaldığı gözlenmiştir. Tedavi esnasında kedilerde ALT, AST, ALP, üre ve kreatinin aktivitelerinin fizyolojik değerler arasında olduğu belirlenmiştir. A. abstinhum ile yapılan in vitro denemelerde tüm gruplarda (tedavi ve kontrol) T.cati yumurtaları içindeki embriyonik gelişimin benzer olduğu gözlenmiştir. A.absinthum ekstresi in vitro ortamda larva gelişimini engellemediği belirlenmiştir.

Sonuç: Bu bitki ekstresi gelecekte parazit hastalıkalıının tedavisi için bir alternatif olabilir. (Turkiye Parazitol Derg 2011; 35: 10-4)

Anahtar Sözcükler: Antiparazitik etki, Artemisia absinthum, kedi, Toxocara cati

Geliş Tarihi: 21.12.2010

Kabul Tarihi: 15.02.2011

This study is presented in $16^{\text {th }}$ National Congress on Parasitology which was held in Adana (1-7 November 2009)

Address for Correspondence / Yazışma Adresi: Dr. Kader Yıldız, Kırıkkale Üniversitesi Veteriner Fakültesi, Parazitoloji Anabilim Dalı, Kırıkkale, Turkey Phone: +90 3183573301 Fax: +90 3183573304 E-mail: kaderyildiz@hotmail.com doi:10.5152/tpd.2011.03 


\section{INTRODUCTION}

Toxocara cati lives in the intestines of cats and other Felidae species (1). This parasite is considered to be one of the most important helminth species of the cat and different rates of its distribution in cats have been reported both in Turkey (2-4) and in various regions of the world (5-7). Different infection routes, such as eating parasite eggs, carrying infectious stage larvae or various paratenic hosts and galactogenic infection have been reported in the life cycle of $T$. cati $(1,8,9)$. Transplacental infection does not occur in the developmental period of T. cati (8). The prepatent period continues approximately 8 weeks with oral infections by eggs which developed infective stage larva (8). Catarrhal inflammation, dehydration, anaemia, weight loss and anorexia can be considered as the most common symptoms in cat with toxocariosis (8).

Many drugs have been developed for the therapy of parasitic infections in animals over the years. Nowadays, alternative therapy choices are increasingly tested for the treatment of parasitic diseases because of resistance development of parasites to antiparasitic drugs, residues in host tissues which was later consumed by humans, and harmful metabolites were excreted with animal faeces to free living arthropods in environment (10-12). Some of the plant extracts have been proved to be successful agents in the treatment of parasitic diseases $(10,13-15)$. One of them is Artemisia absinthium and also known as wormwood. The name "Artemisia" is derived from Goddess Artemis who was said to have discovered the plant's effects, whereas "absinthium" means undrinkable because of the very bitter taste of the plant (16). This plant has been used for therapeutic purpose since the antique Egyptians (16). The dried whole plant and essential oil of $A$. absinthium have traditionally been used as an anthelminthic, antiseptic, antispasmodic and sedative (16). Its essential oil with very bitter taste has also been instigated as a vermifuge which is a more acceptable form. Also, it was reported that wormwood increases the secretions of gastric and pancreatic enzymes and bile in humans (17).

Artemisia absinthium is a well known alternative therapeutic, with particular application in the treatment of nematode infection (16). However, data is absent regarding the impact of wormwood on toxocariosis of cats and additionally its effect on the liver and kidney of cats after administration. In the present study, it was aimed to determine the efficiency of $A$. absinthium extract on cats naturally infected with $T$. cati and on larvated eggs in vitro. The alteration of alanine aminotransferase (ALT), alkaline phosphatases (ALP) and aspartate aminotransferase (AST) in sera are significant for monitoring liver function (18). The alterations of urea and creatinine in sera are essential for monitoring kidney function (18). The second aim was to detect the alterations of $A L T, A L P, A S T$, urea and creatinine in the sera of cats after A.absinthium extract had been administered

\section{MATERIALS AND METHODS}

\section{Composing the trial groups}

In present study, A. absinthium extract was administrated to domestic, shorthair, 2-3 year-old pet female cats naturally infected with $T$. cati in Kırıkkale University, Faculty of Veterinary
Medicine Clinics. The study was approved by the Ethical Committee of Animal Research of Kırıkkale University (file number: 09/13-157). Infected cats were divided into three groups according to the number of $T$. cati eggs per gram (EPG) in faeces. EPG of cats in Group 1 (n:5) and Group 2 (n:3) follows as $150-750$ and $1550-4300$, respectively. EPG of cats in the control group $(n: 3)$ is $300-750$.

\section{Preparing A.absinthium extract}

Artemisia absinthium procured from a local herbal market was identified and authenticated by a botanist. Flower parts of $A$. absinthium plants were granulated manually with a grinder. The oil part of the plants was extracted by the extraction method. The samples were placed in the Soxhlet apparatus. The plant oil extract was obtained by using di-ethyl ether at $30-35^{\circ} \mathrm{C}$ in a 7 hour period. To evaporate di-ethyl ether, the extract was left at room temperature overnight uncovered.

\section{In vivo trial}

The extract of $A$. absinthium diluted in $5 \mathrm{ml}$ of distilled water was given orally to naturally infected cats with plastic syringes without the needle. The extract was administrated as $300 \mathrm{mg} / \mathrm{kg}$ and $600 \mathrm{mg} / \mathrm{kg}$ body weight (b.w.) in Group 1 and 2, respectively. It was given only once a day and the treatment continued for 7 consecutive days. The extracts were prepared fresh before each administration. The extract was given carefully to the cats. The control group was only administrated water. The cat faeces were daily examined both macroscopically and microscopically by using the flotation procedure with saturated salt solution. The alteration of faecal T.cati eggs numbers was detected in animals with the McMaster technique. The faecal analysis was maintained during 8 days after completing the extract administration. The cats were hospitalised during the research period and were fed with commercial dry cat food.

The blood samples were taken by punction of the vena cephalica antebrachi to the tubes with heparin at the $6^{\text {th }}, 12^{\text {th }}, 24^{\text {th }}, 48$ th $72^{\text {th }}$ hours of the treatment period and $21^{\text {th }}$ days after began the treatment period of cats (Group 1, 2 and control group). The activity of ALT, AST, ALP, urea and creatinine were measured with Shimadzu UV-1700 spectrophotometer using the manufacturer's kit (Teco ${ }^{\circledR}$ Diagnostics and DDS diagnostics kits) according to kinetics and endpoint spectrophotometric methods.

\section{In vitro trial}

Toxocara cati eggs were collected from faeces before the extract administrations to naturally infected cats. The collected egg concentration was diluted with PBS as 500 eggs per ml. A. absinthium extract was diluted with distilled water in concentrations of $0.3 \mathrm{mg} / \mathrm{ml}$ and $0.6 \mathrm{mg} / \mathrm{ml}$. Three trial groups were constructed as follows: - $\mathrm{G} 1=0.3 \mathrm{mg} / \mathrm{ml}, \mathrm{G} 2=0.6 \mathrm{mg} / \mathrm{ml}$ and $\mathrm{G} 3=$ control. One $\mathrm{ml}$ of egg solution was added to the glass tubes of each group. Then, one $\mathrm{ml}$ of $A$.absinthium extract was added to egg solutions in tubes $\mathrm{G} 1$ and G2. Only PBS was added in the control group (G3). All groups were incubated in an incubator at $26^{\circ} \mathrm{C}$. The egg samples were taken in the control and trial groups at $24^{\text {th }}$ hours, $7^{\text {th }}, 14^{\text {th }}$ and $21^{\text {th }}$ days, and examined under the light microscope to determine the larval development rate in T. cati eggs. 


\section{RESULTS}

Artemisia absinthium extracts were well tolerated by cats in the present study. We have not seen any side effects in cats that used $A$. absinthium extract. Table 1 represent the efficiency of A.abstinhum extract on the T. cati infection of cats. The faecal eggs number per gram was decreased gradually in the cats of Group 1 (Table 1). In one of the cats (no: 5) in Group 1, the faecal egg output stopped at the $6^{\text {th }}$ day after the treatment started and deformed parasite body was found in the faeces of this cat. The faecal egg output stopped 2 days after the end of the treatment period in another cat (no: 4) but no adult parasite body was found in faeces. The faecal egg output was decreased in other cats in Group 1.

In Group 2, A. absinthium extract dose 600 mg/kg b.w. generally decreased faecal egg number in all the cats examined (Table 1).

In in vitro trials, the embryonic development was identical in all groups. Developed larvae were observed in T. cati eggs at the $21^{\text {th }}$ day. A. absinthium extract did not inhibit larval development in the eggs (Figure 1).

The activity of ALT, AST, ALP, urea and creatinine were observed to be at physiological levels in the sera of cats examined (Table 2).

\section{DISCUSSION}

Toxocara cati is one of the most prevalent nematode parasites found in the cat intestine $(1,8)$. T. cati has attracted great attention zoonotically because of its visceral larvae migrating potential to human $(8,9)$. Today, different medicament choices such as moxidectin, piperazine, fenbendazol, flubendazole, pyrantel, selamectin and milbemycin are available for the treatment of toxocariosis in cats (19-23). However, development of alternative treatment methods has been brought about by veterinarians and researchers.

Artemisia species are known to have antiparasitic efficiency $(11,15,24-26)$. Haemonchus contortus eggs decrease in faeces of sheep after administration of $A$. absinthium extract (26). The effect of extract is expressed as killing the parasite or causing paralysis (26). Larval rate of Trichinella spiralis is decreased in mice muscles following 20 consecutive days administration of 300 and $600 \mathrm{mg} / \mathrm{kg}$ b.w. doses of $A$. absinthium extract (25). In the present study, the doses of $A$. absinthium extract used in the cats were detected according to Caner et al. (25). Artemisia absinthium extract with the doses of $300 \mathrm{mg} / \mathrm{kg}$ and $600 \mathrm{mg} / \mathrm{kg}$ b.w. diminished faecal egg number in all cats naturally infected with $T$. cati in this study. Moreover, the extract completely stopped T. cati eggs in the faeces of two cats in Group 1. The ending of faecal egg output at the $6^{\text {th }}$ day of treatment in one cat (no: 5) in Group 1 may be related to the observed deformed parasite body in faeces of this cat. The faecal egg number, however, was only diminished in Group 2. It was thought that the egg laying potential of $T$. cati may be decreased by $A$. absinthium extract in the present study. However, the larvae development was not inhibited by the extract in the in vitro study. No contraindicative effect was observed in the cats after extract administration.

Artemisia species were divided into two sub-groups with regard to oil composition; one group was characterised by the presence

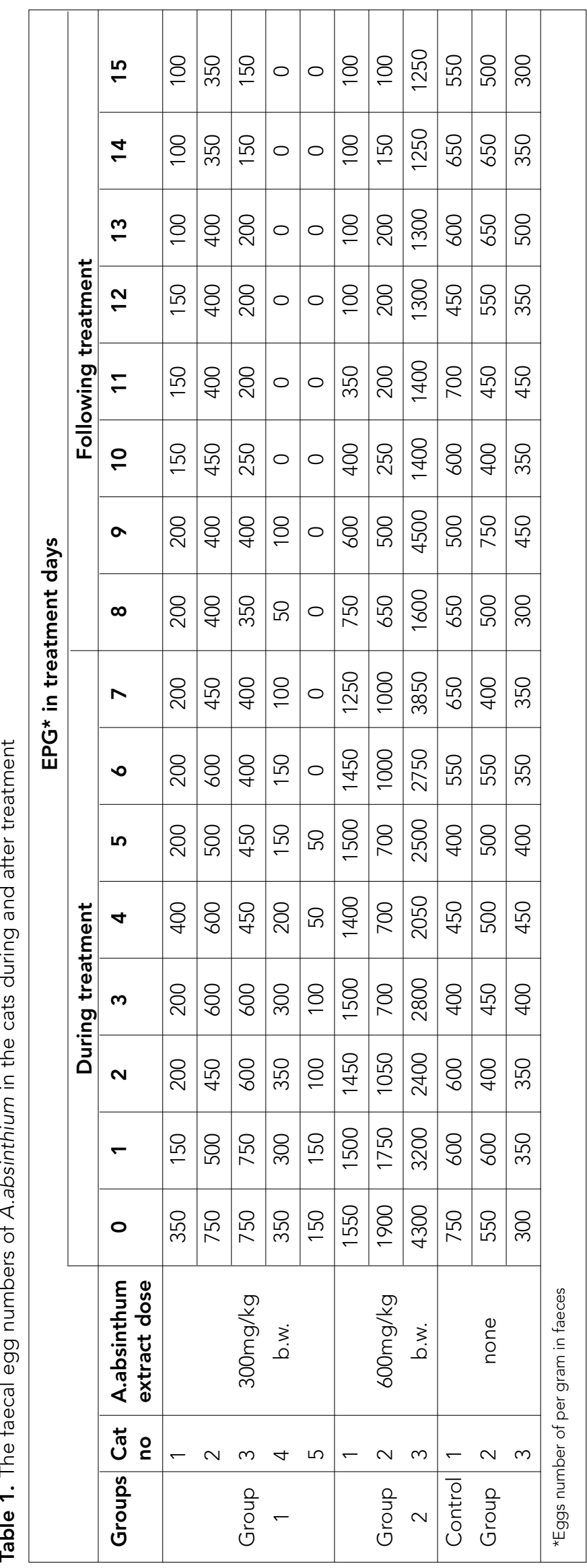


Table 2. Mean serum enzyme levels at various times after the treatment period started in the cats

\begin{tabular}{|c|c|c|c|c|c|c|}
\hline & & $\begin{array}{c}\text { ALT } \\
(U / L)\end{array}$ & $\begin{array}{c}\text { AST } \\
(U / L)\end{array}$ & $\begin{array}{l}\text { ALP } \\
\text { ALP }\end{array}$ & $\begin{array}{c}\text { Urea } \\
(\mathrm{mg} / \mathrm{dl})\end{array}$ & $\begin{array}{l}\text { Creatinine } \\
\text { Creatinine }\end{array}$ \\
\hline Groups & Hours & mean (min-max) & mean (min-max) & mean (min-max) & mean (min-max) & mean (min-max) \\
\hline \multirow{6}{*}{$\begin{array}{l}\text { Group } 1 \\
(n: 5)\end{array}$} & 0 & $18.5(11-32)$ & $19(15-21)$ & $51(35-72)$ & $51.2(45.5-58.6)$ & $1.2(0.9-1.5)$ \\
\hline & 6 & $20.6(14-28)$ & $21.6(14-30)$ & $51.2(38-74)$ & $54.9(46.8-58.8)$ & $1.3(1.2-1.4)$ \\
\hline & 24 & $20.2(18-24)$ & $20.8(11-32)$ & $51.8(41-65)$ & $56.1(45.5-65.3)$ & $1.3(1.2-1.4)$ \\
\hline & 48 & $25.4(14-36)$ & $20.8(14-25)$ & $46(32-62)$ & $56.1(48.0-61.1)$ & $1.3(1.2-1.5)$ \\
\hline & 72 & $20.2(10-24)$ & $20.4(15-24)$ & $47.2(35-58)$ & $55.9(49.5-59.2)$ & $1.2(1.1-1.5)$ \\
\hline & $15^{\text {th }}$ day & $22.3(20-24)$ & $21.2(18-24)$ & $42.3(35-54)$ & $55.2(55.0-58.5)$ & $1.3(1.1-1.4)$ \\
\hline \multirow{6}{*}{$\begin{array}{l}\text { Group } 2 \\
\text { (n:3) }\end{array}$} & 0 & $11(11)$ & $23(23)$ & $48(48)$ & $51.3(51.3)$ & 1.5 (1.5) \\
\hline & 6 & $18.3(15-24)$ & $19.6(14-24)$ & $38(35-42)$ & $50(44.0-55.0)$ & $1.5(1.4-1.6)$ \\
\hline & 24 & $20.3(14-28)$ & $19.6(14-24)$ & $38(35-42)$ & $50.3(48.9-50.8)$ & $1.4(1.4)$ \\
\hline & 48 & $21(15-30)$ & $22.6(19-26)$ & $38.6(33-45)$ & $49.3(45.2-52.0)$ & $1.4(1.3-1.4)$ \\
\hline & 72 & $22.5(20-25)$ & $19(18-20)$ & 34.5 (34-35) & $34.3(44.8-58.0)$ & $1.5(1.5)$ \\
\hline & $15^{\text {th }}$ day & $20.3(19-22)$ & $19.3(18-21)$ & $36.3(30-40)$ & $53.1(48.2-56.5)$ & $1.3(1.2-1.4)$ \\
\hline \multirow{6}{*}{$\begin{array}{l}\text { Control } \\
\text { Group } \\
(n: 3)\end{array}$} & 0 & $15(14-16)$ & $18(16-20)$ & $45(35-65)$ & $50.1(46.4-55.4)$ & $1.2(1.2)$ \\
\hline & 6 & $19.6(17-23)$ & $19.6(17-25)$ & $52.3(48-64)$ & $50.5(44.6-54.3)$ & $1.3(1.2-1.4)$ \\
\hline & 24 & $23.6(21-26)$ & $19(19)$ & $46.3(35-58)$ & $57.7(52.4-60.4)$ & $1.3(1.3)$ \\
\hline & 48 & $24(17-32)$ & $23.6(22-25)$ & $51(39-60)$ & $54.2(52.7-55.6)$ & $1.2(1.1-1.3)$ \\
\hline & 72 & $23(16-29)$ & $22(19-24)$ & $51.3(34-62)$ & $54.0(48.2-57.2)$ & $1.3(1.2-1.4)$ \\
\hline & $15^{\text {th }}$ day & $22.6(19-27)$ & $21.3(21-22)$ & $48.6(41-57)$ & $52.9(47.9-56.8)$ & $1.2(1.1-1.3)$ \\
\hline
\end{tabular}

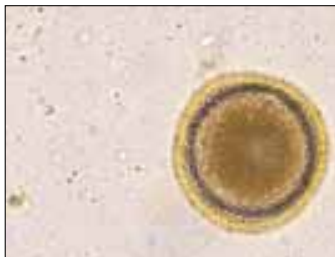

A
B

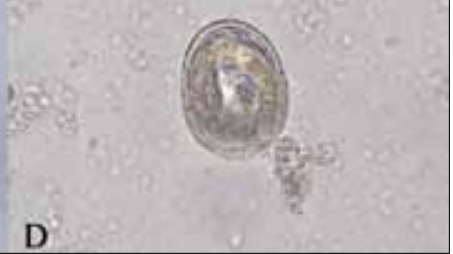

C

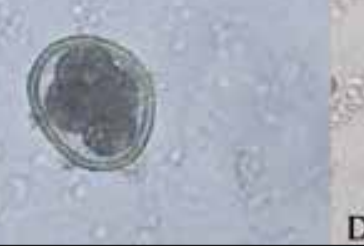

Figure 1. Embryonic development of Toxocara cati eggs in in vitro trial (A: T. cati egg at 24 $4^{\text {th }}$ hour. B: Two blastomeres forms of T. cati egg at $7^{\text {th }}$ day. C: More than four blastomeres in egg at $14^{\text {th }}$ day. D: Developed larvae in $T$. cati egg at $21^{\text {th }}$ day).

of camphor and 1.8-cineole and the second group contained mostly a-thujone (16). Camphor and 1.8-cineole are frequent components of aromatic medicinal herbs, and are reported to have antimicrobial properties (30) and, additionally, these components are known to have antiparasitic efficiency (24). The composition of $A$. absinthium varies from country to country with respect to the soil composition on which it is grown $(27,31,32)$.
The major components of essential oils in Artemisia species produced in Turkey was reported as camphor and 1.8-cineole (27). These essential oils possess an antiparasitic efficiency $(28,29)$. Cineole is reported to have high larvicidal activity on Anisakis simplex L3 (28). Camphor has a strong destructive effect on Demodex spp. in vitro. The main mechanism of camphor oil may be related to direct contact and neuromuscular toxicity (29). The effect of essential oils in $A$. absinthium extracts administrated in our study was mild toxocariosis in the cats.

The presence of liver disorders is often recognized on the basis of elevated serum activities of enzymes of hepatic origin. When hepatic necrosis is present, the serum enzyme activities such as ALT and AST are increased. The liver is exposed to a wide variety of toxins, drugs and drug metabolites that may influence the serum activity of enzymes from the liver (18). There are many possible drugs that stimulate some increase in liver ALP and ALT activities (18). Creatinine and urea are indicators of renal function (18). In our study, the activities of AST, ALT, ALP, creatinine and urea in the sera of cats after the administrated $A$. absinthium extract were located between physiological ranges.

In conclusion, the extract of $A$. absinthium was orally administrated in cats naturally infected with $T$. cati as a preliminary study. Further research on $A$. absinthium may be encouraged with some important results of this study, such as diminished faecal egg output in infected cats, no pathological effect observed on serum activities of the hepatic origin enzymes, creatinine and urea in cat sera after application. However, the difficulty of oral 
administration of $A$. absinthium extracts due to its bitter taste should be overcome. In further studies, the extract of $A$. absinthium can be used at a higher dose than administrated in the present study and placed in capsules delivered to the intestine to facilitate application, or combine with other compounds to increase its effect on parasites. This plant extract may be an alternative choice in the treatment of parasitic diseases in future.

\section{Conflict of Interest}

No conflict of interest is declared by the authors.

\section{REFERENCES}

1. Anderson RC. Nematode Parasites of Vertebrates: Their Development and Transmission. 2. Edition, CABI Publishing 2000.

2. Altaş $M E$, Taşan E. Elazığ kırsal yöre kedilerinde ekto- ve endoparazitler ve bunların halk sağlığı yönünden önemi. Fırat Üniv. Sağlık Bil Derg 1999; 13: 233-42.

3. Ayaz E, Değer $S$, Gül $A$, Yüksek N. Van kedilerinde helmintlerin yayılışı ve halk sağlığı yönünden önemi. Türkiye Parazitol Derg 2001; 25: 166-9.

4. Yaman M, Ayaz E, Gul A, Muz MN. Haya ilinde bakısı yapılan kedi ve köpeklerde helmint enfeksiyonları. Türkiye Parazitol Derg 2006; 30: 200-4.

5. Zibaei M, Sadjjadi SM, Sarkari B. Prevalence of Toxocara cati and other intestinal helminths in stray cats in Shiraz, Iran. Trop Biomed 2007; 24: 39-43.

6. Palmer CS, Thompson RC, Traub RJ, Rees R, Robertson ID. National study of the gastrointestinal parasites of dogs and cats in Australia. Vet Parasitol 2008; 151: 181-90.

7. Sommerfelt IE, Cardillo N, López C, Ribicich M, Gallo C, Franco A. Prevalence of Toxocara cati and other parasites in cats' faeces collected from the open spaces of public institutions: Buenos Aires, Argentina. Vet Parasitol 2006; 140: 296-301.

8. Deplazes P. Helminthosen von Hund und Katze. In: Boch J, Supperer R (eds). Veterinarmedizinische Parasitologie. Parey, Germany, 2006; pp.444-517.

9. Fisher M. Toxocara cati: an underestimated zoonotic agent. Trends Parasitol 2003; 19: 167-70.

10. Akhtar MS, lqbal Z, Khan MN, Lateef M. Anthelmintic activity of medicinal plants with particular reference to their use in animals in Indo-Pakistan subcontinent. Small Rumin Res 2000; 38: 99-107.

11. lqbal Z, Lateef $M$, Ashraf $M$, Jabbar A. Anthelmintic activity of Artemisia brevifolia in sheep. J Ethnopharmacol 2004; 93: 265-8.

12. Steel JW, Wardhaugh KG. Ecological Impact of Macrocyclic Lactones on Dung Fauna. In: Vercruysse J, Rew RS (eds). Macrocyclic Lactones in Antiparasitic Therapy. CABI Publishing, 2002. pp. 141-62.

13. Githiori JB, Hoglund J, Waller PJ. Ethnoveterinary plant preparations as livestock dewormers: practices, popular beliefs, pitfalls and prospects for the future. Anim Health Res Rev 2005; 6: 91-103.

14. Lans C, Turner N, Khan T, Brauer G. Ethnoveterinary medicines used to treat endoparasites and stomach problems in pigs and pets in British Columbia, Canada. Vet Parasitol 2007; 148: 325-40.

15. Mueller MS, Runyambo N, Wagner I, Borrmann S, Dietz K, Heide L. Randomized controlled trial of a traditional preparation of Artemisia annua L. (annual wormwood) in the treatment of malaria. Trans R Soc Trop Med Hyg 2004; 98: 318-21.

16. Deans SG, Kennedy Al. Artemisia absinthum. In: Wright CW (ed) Artemisia. Taylor and Francis 2002; pp.79-89.

17. Baumann IC, Glatzel H, Muth HW. Studies on the effects of wormwood (Artemisia absinthium L.) on bile and pancreatic juice secretion in man. Z Allgemeinmed 1975; 51: 784-91.

18. Hoffmann WE, Solter PF. Diagnostic Enzymology of Domestic Animals. In: Kaneko JJ, Harvey JW, Bruss ML (eds). Clinical Biochemistry of Domestic Animals. Academic Press, sixth edition, 2008; .pp. 351-78.

19. Bowman DD, Lynn RC, Eberhard ML, Alcaraz A. Georgi's Parasitology for Veterinarians. Saunders, Elsevier 2003

20. Reinemeyer CR, Charles SD, Buch J, Settje T, Altreuther G, Cruthers $L$, et al. Evaluation of the efficacy of emodepside plus praziquantel topical solution against ascarid infections (Toxocara cati or Toxascaris leonina) in cats. Parasitol Res 2005; 97: 41-50.

21. Ridley RK, Terhune KS, Granstrom DE. The efficacy of pyrantel pamoate against ascarids and hookworms in cats. Vet Res Commun 1991; 15: 37-44.

22. Schenker R, Bowman D, Epe C, Cody R, Seewald W, Strehlau G, et al. Efficacy of a milbemycin oxime-praziquantel combination product against adult and immature stages of Toxocara cati in cats and kittens after induced infection. Vet Parasitol 2007; 145: 90-3.

23. Wolken S, Schaper R, Mencke N, Kraemer F, Schnieder T. Treatment and prevention of vertical transmission of Toxocara cati in cats with an emodepside/praziquantel spot-on formulation. Parasitol Res 2009; 105: 75-81

24. Allen PC, Lydon J, Danforth HD. Effects of components of Artemisia annua on coccidia infections in chickens. Poult Sci 1997; 76: 1156-63.

25. Caner A, Doskaya M, Degirmenci A, Can H, Baykan S, Uner A, et al. Comparison of the effects of Artemisia vulgaris and Artemisia absinthium growing in western Anatolia against trichinellosis (Trichinella spiralis) in rats. Exp Parasitol 2008; 119: 173-9.

26. Tariq KA, Chishti MZ, Ahmad F, Shawl AS. Anthelmintic activity of extracts of Artemisia absinthium against ovine nematodes. Vet Parasitol 2009; 160: 83-8.

27. Kordali S, Cakir A, Mavi A, Kilic H, Yildirim A. Screening of chemical composition and antifungal and antioxidant activities of the essential oils from three Turkish artemisia species. J Agric Food Chem 2005; 53: 1408-16.

28. Navarro MC, Noguera MA, Romero MC, Montilla MP, González de Selgas JM, Valero A. Anisakis simplex s.l.: Larvicidal activity of various monoterpenic derivatives of natural origin against L3 larvae in vitro and in vivo. Exp. Parasitol 2008; 120: 295-9.

29. Ya'e Z, Na G, Rui S, Lingxiao Z. The effect and mechanism of new natural miticide camphor oil in killing Demodex. J. Xi'an Jiantong Univ. (Med Sci) 2006; 27: 6

30. Lopes-Lutz D, Alviano DS, Alviano CS, Kolodziejczyk PP. Screening of chemical composition, antimicrobial and antioxidant activities of Artemisia essential oils. Phytochemistry 2008; 69: 1732-8.

31. Morteza-Semnani K, Akbarzadeh M. Essential oils composition of Iranian Artemisia absinthium L. and Artemisia scoparia Waldst.et Kit. J Essent Oil Res 2005; 17: 321-2.

32. Orav A, Raal A, Arak E, Mürisepp M, Kailas T. Composition of the essential oil of Artemisia absinthium L. of different geographical origin. Proc Estonian Acad Sci Chem 2006; 55: 155-65. 